\title{
Het recht op autonomie in samenhang met goede zorg bezien
}

\author{
Prof. mr. A.C. Hendriks, mr. dr. B.J.M. Frederiks en prof. dr. M.A. Verkerk ${ }^{I}$
}

Het Europees Hof voor de Rechten van de Mens (EHRM) heeft onlangs het recht op persoonlijke autonomie onomwonden erkend. ${ }^{2}$ Dit vormt een doorbraak, daar het Hof eerder het bestaan van een 'recht op zelfbeschikking' expliciet had afgewezen. ${ }^{3}$ Autonomie en zelfbeschikking zien volgens het Hof op belangrijke aspecten van het privé-leven van personen, meer in het bijzonder hun fysieke en sociale identiteit, ${ }^{4}$ en vormen met betrekking tot de gezondheidszorg de grondslag om een medische behandeling te weigeren. ${ }^{5}$

De Nederlandse patiëntenwetgeving is gestoeld op een soortgelijke autonomiegedachte. De idee dat zelfbeschikking een subjectief recht is heeft hier te lande al eerder postgevat, onder meer bij gezondheidsrechtjuristen. ${ }^{6}$ Autonomie wordt hierbij gezien als tegenpool van paternalisme, betutteling en andere vormen van externe bemoeienissen en afhankelijkheid (heteronomie). . Een vrije, geëmancipeerde persoon is een individu, dat zijn eigen leven vorm geeft zonder dat anderen of zijn psychische of fysieke vermogens hem daarbij restricties opleggen. ${ }^{8}$

De op de individuele zelfbeschikking gebaseerde Nederlandse patiëntenrechten ${ }^{9}$ gaan ervan uit dat iedere patiënt voor zichzelf bepaalt welke zorg bij hem past. ${ }^{\text {Io }}$ Deze keuzevrijheid houdt ook in dat zorg mag worden geweigerd, dat mag worden gekozen voor alternatieve zorg en dat (reguliere) gezondheidsadviezen mogen worden genegeerd. Kortom, het individuele ('persoonlijke') autonomieconcept, dat zelfbeschikking en keuzevrijheid waarborgt, wordt als afweerrecht in stelling gebracht.

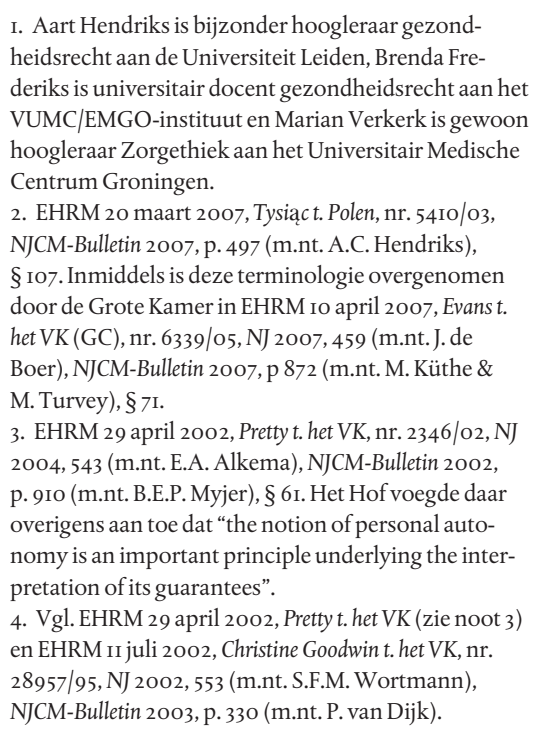

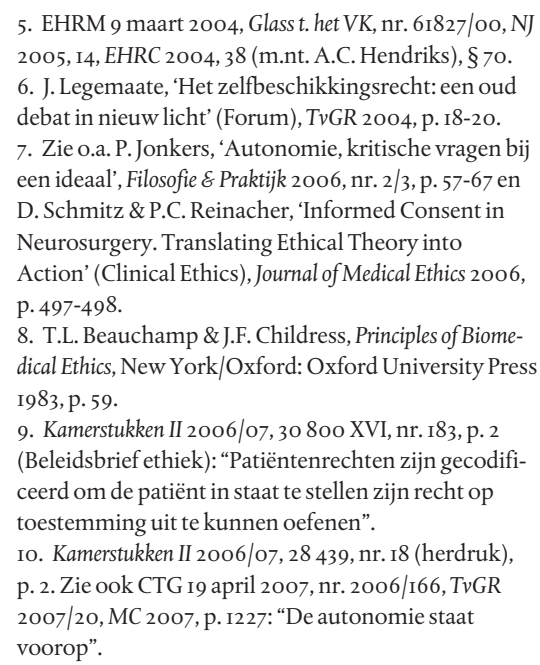


De vraag is echter of het recht op persoonlijke autonomie, zoals erkend door het EHRM, wel in deze zin moet worden opgevat. Of vormt de erkenning van het Hof van deze aanspraak juist aanleiding de wijze waarop het autonomieconcept in Nederland doorgaans wordt uitgelegd te heroverwegen?

De afgelopen jaren valt er vanuit zowel het juridische als het ethische discours kritiek te beluisteren op de vereenzelviging van (patiënten)rechten met zelfbeschikking in termen van een vrijwel absolutistische aanspraak op individualiteit, onafhankelijkheid en keuzevrijheid. De aandacht voor deze - volgens Dworkin - evidentiary view op autonomie ${ }^{\mathrm{II}}$ zou ten koste gaan van de goede zorg voor de patiënt en onverenigbaar zijn met de waarden die ten grondslag liggen aan ons recht. ${ }^{12}$ Een dergelijke - individualistische - visie op autonomie kan een bedreiging vormen voor de waardigheid van de meest kwetsbaren in onze samenleving, waaronder mensen met een psychiatrische stoornis, een verstandelijke beperking of dementie. ${ }^{13}$ Zelfbeschikking kan dan een titel vormen om deze en andere mensen goede zorg te onthouden. "Dit alles roept de vraag op" aldus A-G Langemeijer, "of het zelfbeschikkingsrecht ... zich niet tegen de patiënt keert". ${ }^{4}$

Autonomie en goede zorg belichamen, zoals hieronder nader uiteen zal worden gezet, belangrijke waarden. Zij vormen beide noodzakelijke modaliteiten van de menselijke waardigheid. Dit verklaart, in een notendop, de toenemende roep om in wetgeving en beleid het evenwicht te herstellen tussen autonomie en goede zorg. ${ }^{15}$ Door beide tegen elkaar uit te spelen, in plaats van met elkaar te verbinden, ontstaat er een disbalans, die zich onder meer heeft vertaald in kritiek op de huidige Wet bijzondere opnemingen in psychiatrische ziekenhuizen (Wet Bopz).

In het navolgende zal worden betoogd dat de betekenis van het 'recht op persoonlijke autonomie', uitgaande van de menselijke waardigheid, moeilijk anders dan in nauwe samenhang met het beginsel van goede zorg kan worden bezien. Deze invulling van het autonomieconcept impliceert onder meer dat er, meer dan thans doorgaans het geval is, aandacht dient te worden besteed aan relationele aspecten en de aanspraken die individuen hieraan jegens hulpverleners kunnen ontlenen.

De opbouw van deze bijdrage is als volgt. Allereerst wordt ingegaan op de juridische - met name de gezondheidsrechtelijke-interpretatie en de wettelijke grondslag van de begrippen autonomie (par. 2) en goede zorg (par.3), om vervolgens een link te leggen naar het beginsel van menselijke waardigheid (par. 4). Vervolgens beschrijven wij de verbreding van het autonomieconcept, zoals voorgestaan door het EHRM (par. 5), om aansluitend te bezien wat hiervan de consequenties zijn voor ons (gezondheids)recht (par. 6). De belangrijkste conclusies vatten wij tot slot kort samen (par. 7).

II. R. Dworkin, Life's Dominion, New York: Vintage Books I993, p. 223.

I2. G. Dworkin, The Theory and Practice of Autonomy, Cambridge: Cambridge University Press I988, p. 23. Zie ook W. Thomassen, Fundamentele waarden in het recht (oratie EUR), Den Haag: Boom Juridische uitgevers 2007

I3. G. Widdershoven \& R. Berghmans, 'Coercion and pressure in psychiatry: lessons from Ulysses', Journal of Medical Ethics 2007, p. 560-563.
I4. HR 29 april 2004, BJ 2005, I5 (m.nt. T.P. Widdershoven).

I5. Vgl. Kamerstukken II 2006/07, 20 492, nr. 7, p. I. Zie ook de Beleidsbrief ethiek, p. 3 (noot 9) en het - door Nederland nog niet geratificeerde-Verdrag inzake de rechten van personen met een handicap, Trb. 2007, I69. 
Het autonomiebeginsel neemt sinds het eind van de jaren zestig van de vorige eeuw binnen het toen nog prille gezondheidsrecht een centrale plaats in. ${ }^{16}$ Autonomie wordt daarbij veelal vereenzelvigd met het recht zonder bemoeienis van anderen richting te geven aan het leven: de mens stelt zichzelf (auto) wetten (nomos). Vandaar dat ook vaak wordt gesproken van zelfbeschikking. De gezondheidsrechtjurist Leenen was één van de eerste pleitbezorgers van deze autonomieopvatting, zonder overigens het belang van goede zorg te miskennen. In de eerste druk van zijn befaamde handboek stelt hij dat het zelfbeschikkingsrecht van de mens een basisrecht is, dat aan andere wel in de Grondwet of andere officiële documenten opgenomen grondrechten ten grondslag ligt. ${ }^{17}$ Het betreft hier een fundamenteel recht, waaraan - aldus Leenen in voorkomende gevallen meer gewicht toekomt dan het recht op leven en het recht op lichamelijke integriteit. ${ }^{18}$ Hoewel deze opvatting van Leenen niet bij alle vakgenoten op instemming kon rekenen, ${ }^{19}$ is deze visie op zelfbeschikking sindsdien dominant in het Nederlandse gezondheidsrecht en de gezondheidsethiek.

De gedachte dat autonomie het belangrijkste recht is van de patiënt heeft duidelijk weerslag gevonden in de patiëntenwetgeving, zoals die sinds de jaren zeventig tot stand is gekomen. ${ }^{20}$ Dit geldt in het bijzonder voor de wettelijke regeling inzake de geneeskundige behandelingsovereenkomst (Afdeling 7.7.5. van het Burgerlijk Wetboek) en de Wet Bopz, waarbinnen het recht op informatie en het recht op toestemming (samen: informed consent) als uitdrukking van individuele zelfbeschikking de hoeksteen vormen.

In het verlengde hiervan wordt autonomie in het gezondheidsrechtelijke discours primair in verband gebracht met de 'vrijheid van', het richting kunnen geven aan het eigen leven zonder externe bemoeienissen. Autonomie, aldus opgevat, vormt een uitwerking van het recht op privacy en het recht op lichamelijke integriteit, zoals neergelegd in artikel 8 van het Europees Verdrag tot bescherming van de rechten van de mens en fundamentele vrijheden (EVRM) en de artikelen Io en II van de Grondwet $(\mathrm{Gw})$.

Tegenover dit afweerrecht van het individu staat dat ieder mens het recht heeft zich te ontwikkelen en te ontplooien, en zijn leven vorm te geven in overeenstemming met wie hij is en wat hij wil. In navolging van Berlin wordt dit recht wel aangeduid met de term 'vrijheid tot'. ${ }^{2 \mathrm{I}}$ Dit laatste veronderstelt dat de overheid enerzijds de (materiële) voorwaarden schept om vrij te zijn (freedom from want) en anderzijds maatregelen

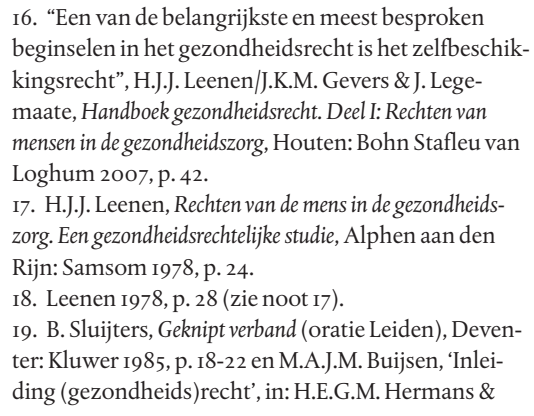

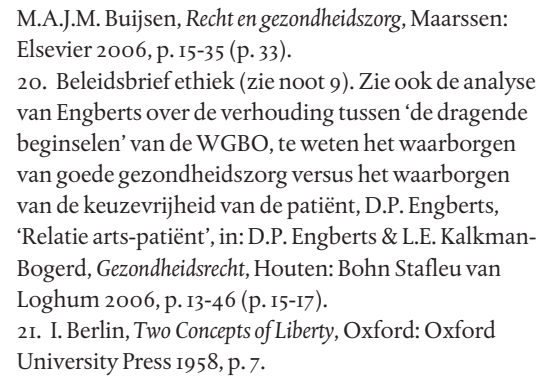


treft ter verwezenlijking van de immateriële vrijheid. 'Vrijheid tot' impliceert ook - bijvoorbeeld in het kader van hulpverleningsrelaties - dat individuen worden ondersteund bij het maken van keuzes, onder meer door het geven van informatie toegespitst op de betrokkene, het aanreiken en bespreken van alternatieven en het duidelijk maken van de risico's die patiënten lopen als ze een bepaalde beslissing nemen. Maar de 'vrijheid tot' brengt voor hulpverleners ook de plicht mee de patiënt bij te staan in het verhelderen van zijn wensen en verlangens die een rol spelen in de besluitvorming. In deze positieve vrijheidsopvatting gaat het niet alleen om het feit dat mensen vrije keuzes kunnen maken, maar is het ook van belang welke keuzes zij maken. Is de keuze inderdaad door de patiënt gewenst of is zij het resultaat van verwardheid of onzekerheid? De eisen van het goed hulpverlenerschap (art. 7:453 BW) en de plicht 'verantwoorde zorg' te bieden (art. 40 Wet BIG resp. art. 2 Kwaliteitswet zorginstellingen, KWZ) bieden, in aanvulling op de eis van informed consent (art. 7:448-450 BW), waarborgen om gebruik te maken van de 'vrijheid tot' en zich te onttrekken aan de heteronomie. Een goede zorgrelatie, hetgeen deze eisen veronderstellen, vraagt om vertrouwen, betrokkenheid en goede communicatie tussen hulpverlener en patiënt.

Hoewel autonomie in de hoedanigheid van 'vrijheid tot' ontegenzeggelijk erkenning heeft gevonden in Nederland, wordt autonomie in het gezondheidsrechtelijke discours bovenal opgevat als afweerrecht, waarbij het zelf beslissen door de patiënt voorop staat. ${ }^{22}$ Het beperken van de betekenis van autonomie tot een negatief vrijheidsideaal, met de nadruk op keuzevrijheid - een gedachte die we bij recente wetgevingsoperaties regelmatig terugzien ${ }^{23}$ - is de laatste jaren aan kritiek onderhevig. Door sommige juristen wordt gewezen op het gevaar dat autonomie een titel dreigt te worden voor egoïsme en het ongebreideld najagen van het eigenbelang, waartegen - ook juridisch - bezwaren bestaan. ${ }^{24}$ Immers, de vrijheid zelf richting te geven aan het leven is - anders dan de redelijkheid waarvan Kant uitging ${ }^{25}$ - juridisch niet aan bepaalde criteria gebonden, althans voor zover de betrokkene geen gevaar vormt voor anderen of de rechten en vrijheden van anderen schendt. Daarnaast is de zelfbeschikking van personen met een psychiatrische stoornis of een verstandelijke beperking ongewis. In het kader van de hulpverlening wordt het zelfbeschikkingsbeginsel soms snel terzijde geschoven (vgl. de behandeling van mensen met een verstandelijke beperking), dan weer als beletsel gezien voor het bieden van goede zorg met als gevolg dat de zelfbeschikking dreigt te worden uitgehold (vgl. de behandeling van mensen met een ernstige eetstoornis). Eveneens is het moeilijk te begrijpen waarom de vrijheid om zelf richting te geven aan het leven in de rechtspraktijk soms ondergeschikt wordt gemaakt aan andere belangen, waaronder de bescherming van de gezondheid van de betrokkene. ${ }^{26}$

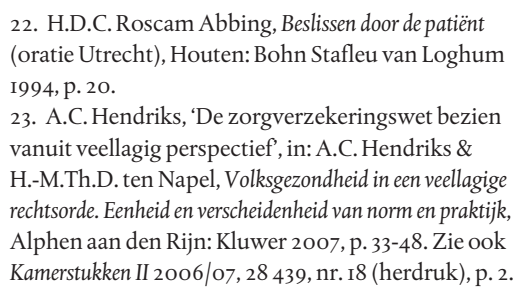

22. H.D.C. Roscam Abbing, Beslissen door de patiënt (oratie Utrecht), Houten: Bohn Stafleu van Loghum I994, p. 20.

23. A.C. Hendriks, 'De zorgverzekeringswet bezien vanuit veellagig perspectief', in: A.C. Hendriks \&

H.-M.Th.D. ten Napel, Volksgezondheid in een veellagige rechtsorde. Eenheid en verscheidenheid van norm en praktijk, Alphen aan den Rijn: Kluwer 2007, p. 33-48. Zie ook Kamerstukken II 2006/o7, 28 439, nr. I8 (herdruk), p. 2.

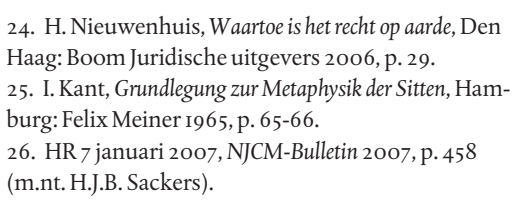

24. H. Nieuwenhuis, Waartoe is het recht op aarde, Den Haag: Boom Juridische uitgevers 2006, p. 29. 25. I. Kant, Grundlegung zur Metaphysik der Sitten, Hamburg: Felix Meiner 1965, p. 65-66.

26. HR 7 januari 2007, NJCM-Bulletin 2007, p. 458 (m.nt. H.J.B. Sackers). 
Ook vanuit gezondheidsethisch gezichtspunt is kritiek geformuleerd op het individualistische autonomiebegrip en het onderliggende mensbeeld. Het autonomieconcept is gestoeld op een zelfbeeld van het individu, waarin vrijheid, individualiteit, rationaliteit en onafhankelijkheid centraal staan. Een dergelijk mensbeeld past niet goed bij mensen die ziek en patiënt zijn. Mensen met gezondheidsproblemen zijn vaak extra kwetsbaar en ongewoon afhankelijk van anderen voor zorg en ondersteuning. Patiënten zijn op hun best partieel autonoom of zelfbeschikkend, zou de filosofe O'Neill stellen. ${ }^{27}$ Dat betekent ook dat een zorgrelatie uitsluitend gebaseerd op deze liberale omgangsregels een verschraalde zorgrelatie oplevert. De patiënt is niet een vrije keuzemaker en de zorgverlener is niet iemand die slechts keuzealternatieven aanreikt en zich voor het overige afzijdig houdt. ${ }^{28}$ De patiënt is daarentegen vaak iemand die anderen nodig heeft om te weten wat hij nu werkelijk nodig heeft om te kunnen floreren. ${ }^{29}$ Dat vraagt om hulpverleners die zich niet uitsluitend houden aan het geven van informatie, maar zich ook willen opstellen als raadgever en meedenker voor de patiënt. Daarmee wordt overigens de deur niet opnieuw wagenwijd geopend voor een ongebreideld paternalisme. Goed hulpverlenerschap houdt immers ook in dat de hulpverlener zich ten overstaan van patiënt en zijn beroepsgenoten kan verantwoorden voor zijn handelen en waarbij een gezamenlijk beslissen ('shared-decisionmaking') voorop staat.

Een herbezinning op het autonomieconcept, dat meer recht doet aan de interdependentie en de relationele aspecten van het menselijk bestaan alsmede de noodzaak in bepaalde situaties zorg en steun te bieden, is daarom nodig. ${ }^{30}$ In een dergelijke relationele optiek betekent autonomie vooral dat mensen in staat zijn hun leven als van henzelf te ervaren. Vanuit deze optiek wordt de 'vrijheid tot' of de 'positieve vrijheid' als 'authenticiteit' benadrukt. Het autonome zelf is daarbij geen statisch gegeven, maar iets waarnaar wordt toegewerkt. ${ }^{31} \mathrm{Het}$ zelf is een dynamisch zelf dat steeds in ontwikkeling blijft, wat ook met zich brengt dat telkens moet worden gevraagd of deze beslissing of die keuze er één is die bij het zelf past. Keuzes veranderen immers het zelf ook weer. Daarmee is het geraken tot autonomie, tot zelfbegrip, als het ware zelf ook een proces. De rol van anderen is daarbij onmisbaar. Alleen in relatie met anderen en zijn omgeving kan een individu ontdekken wat hij werkelijk wil. Goede zorg en goed hulpverlenerschap staan als het ware in dienst om die vrijheid teweeg te brengen. Een hulpverlener zal die zorg verlenen die de patiënt ook benodigd en die hem ook laat zijn wie hij is.

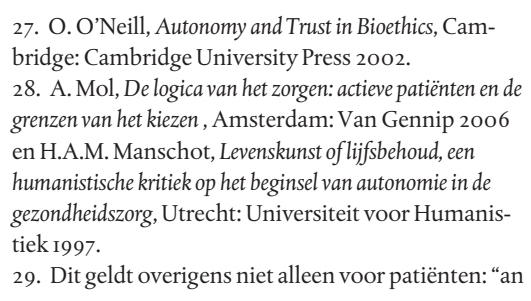

27. O. O'Neill, Autonomy and Trust in Bioethics, Cambridge: Cambridge University Press 2002.

28. A. Mol, De logica van het zorgen: actieve patiënten en de grenzen van het kiezen, Amsterdam: Van Gennip 2006 en H.A.M. Manschot, Levenskunst of lijfsbehoud, een humanistische kritiek op het beginsel van autonomie in de gezondheidszorg, Utrecht: Universiteit voor Humanistiek 1997.

29. Dit geldt overigens niet alleen voor patiënten: “an

individual human person cannot develop and achieve the fullness of his potentials without the concrete act of relating to other individual persons", K. Gyekye, 'Persons and community in African Thought', in: P.H. Coetzee \& A.P.J. Roux (red.), Philosophy from Africa, Cape Town: Oxford University Press I998, p. 32I. 30. Widdershoven \& Berghmans 2007 (zie noot I3). 31. M. Schreurs, 'Autonomie, een humanistisch pleidooi', Filosofie \& Praktijk 2006, nr. 2/3, p. 68-77 (p. 77). 
Met het bovenstaande is niet gezegd dat in het (gezondheids)recht en de gezondheidsethiek absolute betekenis toekomt aan zelfbeschikking. Het (gezondheids)recht benadrukt immers ook de eisen van het goed hulpverlenerschap en van het bieden van 'verantwoorde zorg.' ${ }^{32}$ Deze eisen beogen de patiënt ook te beschermen. In het recht zien we deze beschermingsgedachte terug in het solidariteitsbeginsel en de daarop gebaseerde sociale grondrechten. ${ }^{33}$ In de ethiek klinkt deze gedachte door in de beginselen van 'niet schaden' en 'goed doen'. ${ }^{34}$ In de recentelijk gepubliceerde beleidsbrief ethiek wordt in dezen gesproken over 'de beschermwaardigheid van het leven' en 'goede zorg'. ${ }^{35}$

Wat wordt nu verstaan onder goede zorg? Goede zorg is zorg die individueel gericht is, in de zin van aansluitend bij de wensen en behoeften van de patiënt, en bijdraagt aan de ontplooiing - in de zin van zelfverwerkelijking en authenticiteit - van de betrokkenen. ${ }^{36}$ Kelk voegt hieraan toe dat "het recht op goede zorg ook te beschouwen is als een intentieverklaring van de wijze waarop de patiënt vanwege het instituut waar hij verblijft, zal worden verzorgd, begeleid, behandeld en tegemoet wordt getreden". ${ }^{37}$ Dit veronderstelt ook dat de hulpverlener zijn handelen inzichtelijk maakt en bereid is tot het afleggen van verantwoording aan derden, opdat de kwaliteit van zorg toetsbaar is.

Volgens de vigerende wetgeving rust er op zorgaanbieders niet slechts een publiekrechtelijke verplichting tot het bieden van 'verantwoorde zorg'(art. 40 Wet BIG resp. art. $2 \mathrm{KWZ),} \mathrm{maar} \mathrm{zijn} \mathrm{hulpverleners} \mathrm{ook} \mathrm{-} \mathrm{zoals} \mathrm{hierboven} \mathrm{is} \mathrm{aangegeven} \mathrm{-} \mathrm{via} \mathrm{de} \mathrm{'eis}$ van het goed hulpverlenerschap'(art. 7:53 BW) gehouden tot het bieden van goede zorg, een eis die ook plichten met zich brengt. ${ }^{38}$ Met betrekking tot deze laatste norm geldt dat de hulpverlener de zorg moet betrachten die de redelijk bekwaam en redelijk handelend vakgenoot in dezelfde omstandigheden zou hebben betracht. ${ }^{39}$ Dit kwalitatieve uitgangspunt laat onverlet dat de in deze eis besloten liggende plicht voor hulpverleners om goede zorg te bieden op verschillende manieren kan worden uitgelegd. ${ }^{40}$ Indien wordt aangesloten bij de (negatieve) autonomie van de patiënt, ${ }^{4 \mathrm{I}}$ in de eerder beschreven zin, lijkt goed hulpverlenerschap bovenal een bevestiging van het uitgangspunt dat een hulpverlener slechts op basis van niet-directieve informatie en

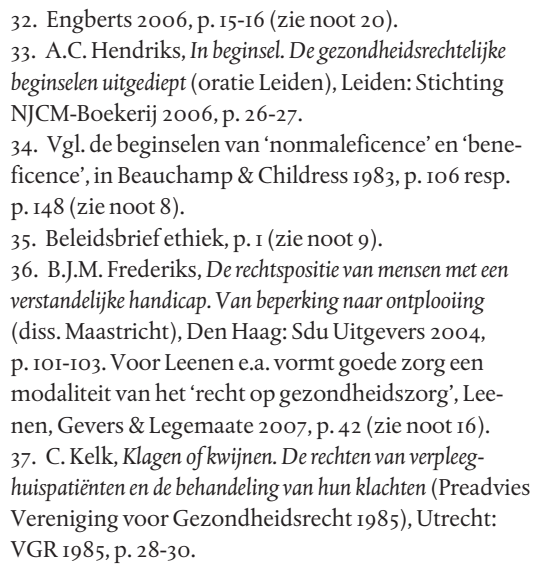

38. RTG Amsterdam I3 maart 2007, GJ 2007, II6, TvGR $2007 / 27$.

39. Zie reeds HR 9 november I990, NJ I99I, 26, TvGR I99I/I8. Later herhaald in o.a. HR I april 2005, NJ 2006 377 (m.nt. H.J. Snijder \& F.C.B. van Wijmen), TvGR 2005/19.

40. A.R. Maclean, 'Autonomy, Consent and Persuasion', European Journal of Health Law 2006, p. 32I-338. 4I. Zulks ter onderscheiding van de medischprofessionele autonomie, een term waarmee wordt gedoeld op de vrijheid en eigen verantwoordelijkheid van de leden van de medische beroepsgroep, uitgaande van deskundigheid en professionaliteit. Vgl. het KNMG-manifest Medische professionaliteit, Utrecht: KNMG 2007. 
daaropvolgende vrijwillige toestemming medisch geïndiceerde zorg mag geven. Zorgverlening is dan een eenrichtingsverkeer, waarbij de patiënt - de 'opdrachtgever' volgens de patiëntenwetgeving - zijn autonome wensen kenbaar maakt en de hulpverlener afhankelijk daarvan handelt. Indien deze eis meer in verband wordt gebracht met het beginsel van goede zorg, dan is deze norm veeleer de codificatie van de professionaliteit - ook wel aangeduid als 'medisch professionele autonomie' - van hulpverleners uitgaande van een zoveel mogelijk op wederzijds vertrouwen gebaseerde relatie. Een goed hulpverlener tracht niet alleen te achterhalen wat de wil is van zijn patiënt, maar de patiënt moet er ook anderszins op kunnen vertrouwen dat de hulpverlener zich primair laat leiden door hetgeen in het gezondheidsbelang is van die patiënt, waarbij de standaarden van de beroepsgroep met betrekking tot de te verstrekken zorg leidend zijn. Dit laatste impliceert ook dat een hulpverlener gerechtigd, zo niet verplicht, is om geen zorg te bieden die niet aan dit criterium voldoet. ${ }^{42}$

Goede zorg, aldus bezien, brengt ook met zich dat hulpverleners ongevraagd bescherming bieden aan individuen en, in voorkomende gevallen, overgaan tot (be)handelen zonder dat (vooraf) sprake is van informed consent. ${ }^{43}$ Het gaat immers om een actieve beschermingsplicht die is gericht op het stimuleren van de mogelijkheden en de ontplooiingskansen van een patiënt, ongeacht of deze persoon meer- of minderjarig is en wel of niet wilsbekwaam. De aandacht verschuift van niet-inmenging naar het actief bieden van ondersteuning en bescherming, maximaal rekening houdend met de (vrijheids)rechten van de betrokkenen. ${ }^{44}$ Vanwege dit laatste vormt wilsbekwaamheid een belangrijk, maar niet een allesbepalend criterium bij beslissingen inzake het bieden van zorg. Deze beschermingsgedachte heeft ook consequenties voor de uitleg en naleving van zelfbindingsverklaringen en andere op toekomstige situaties ziende schriftelijke wilsuitingen van de patiënt. ${ }^{45}$

Goede zorg veronderstelt derhalve een actieve zorgplicht van hulpverleners. Hoewel wilsbekwaamheid een belangrijke factor vormt bij het actief (aan)bieden van bescherming en het verkrijgen van toestemming is dit niet allesbepalend bij de beoordeling of dat is gelegitimeerd. ${ }^{46}$ Ook wilsbekwame personen maken aanspraak op 'vrijheid tot', vanuit welke optiek het nodig kan zijn hen op het juiste spoor te zetten ter verkrijging van voor hen passende zorg.

Deze opvatting over goede zorg impliceert een vertrouwensrelatie tussen de hulpverlener en de patiënt, waarbinnen het handelen van de hulpverlener niet slechts afhankelijk is van de door de patiënt gemaakte keuze tussen verschillende behandelingsopties. Was er het gevaar dat vanuit een strikt individualistische invalshoek de zorgrelatie tot een verschraalde betrekking tussen mensen verwordde, vanuit een opvatting van goede zorg wordt het relationele en betrokken aspect van deze relatie benadrukt. Binnen het zorgperspectief wordt hulpverlenen niet gezien als het aanbie-

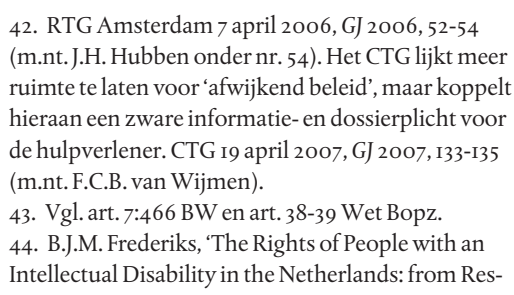

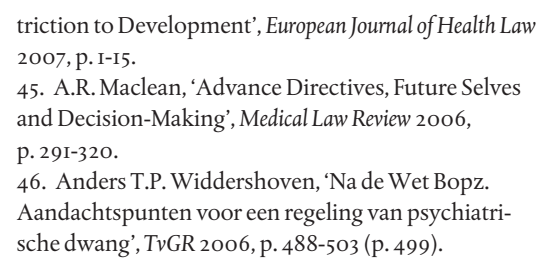


den van bepaalde zorgproducten waarop een patiënt 'ja' of 'nee' kan zeggen. Goede zorg veronderstelt dat de hulpverlener met aandacht voor en in overleg met de patiënt nagaat welke zorgbehoeften deze heeft en wat in diens belang is, waarop de hulpverlener vervolgens op verantwoordelijke en competente wijze handelt en waarbij ook de patiënt zich ontvankelijk opstelt voor de zorg die wordt geboden. Aldus opgevat kan goede zorg - juridisch via de boeg van de eisen van het goed hulpverlenerschap en verantwoorde zorg - bijdragen aan het versterken, althans (trachten te) herstellen, van de autonomie, in plaats van dat het hieraan afbreuk doet.

De bescherming van de menselijke waardigheid belichaamt de meest fundamentele waarde van ons recht en daarmee van het gezondheidsrecht. Menselijke waardigheid ligt aldus ook ten grondslag aan de inkleuring van de begrippen autonomie en goede zorg.

Maar wat is nu de precieze betekenis van menselijke waardigheid? Hoewel in gezondheidsrechtelijke discussies vaak op dit begrip wordt teruggegrepen, laat dit zich moeilijk eenduidig definiëren. ${ }^{47}$ In de rechtswetenschappelijke en (gezondheids)ethische literatuur zien we dat menselijke waardigheid op, grofweg, twee manieren wordt uitgelegd: waardigheid in termen van emancipatie van mensen en waardigheid in de zin van beperking voor menselijk handelen. ${ }^{48}$

In de eerste visie wordt menselijke waardigheid bovenal - of uitsluitend ${ }^{49}$ - gezien als normatieve grondslag ter onderstreping van het belang van de persoonlijke autonomie. Menselijke waardigheid staat voor de aanhangers van deze op de verlichtingsfilosofie gestoelde visie gelijk aan empowerment. ${ }^{50}$ De nadruk ligt op keuzevrijheid en zelfbeschikking, zonder inhoudelijke, substantieve criteria waaraan de autonomie kan worden beoordeeld ('autonomy as a purely formal notion' ${ }^{\text {'I }}$ ). Mensenrechten zijn, in het verlengde hiervan, primair afweerrechten. Het niet of onvoldoende verstrekken van informatie aan een patiënt wordt in deze visie gezien als een inperking van de autonomie en de menselijke waardigheid van de betrokkene. ${ }^{52}$

Tegenover deze empowerment-visie zijn er auteurs die menselijke waardigheid veeleer zien als normatieve noodzaak om mensen beperkingen op te leggen ter voorkoming dat zij grenzen overschrijden die inherent zijn aan de dignitas. Hierbij kan bijvoorbeeld worden gedacht aan de argumenten die naar voren worden gebracht in discussies rond kunstmatige voortplanting, gentherapie, kloneren en stamcelonderzoek. ${ }^{53}$ Maar ook meer in algemene zin impliceert menselijke waardigheid als constraint dat er grenzen zijn aan de individuele (keuze)vrijheid. Zo moet het indi-

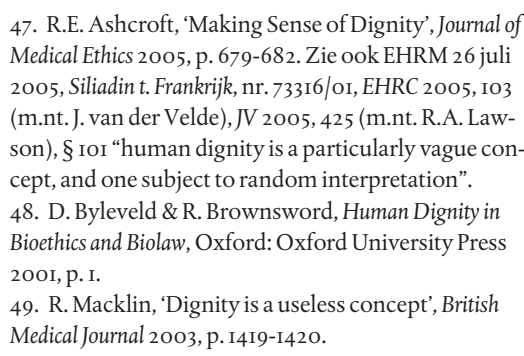

50. Nieuwenhuis 2006, p. 29 (zie noot 24).

5I. Dworkin I988, p. I2 (zie noot I2).

52. Vgl. House of Lords I4 oktober 2004, Chester t. Afshar, [2004] 4 All E.R. 587. Eenzelfde visie lijkt ten grondslag te liggen aan het arrest van de HR in de zaak van Baby Kelly, HR I8 maart 2005, NJ 2006, 606 (m.nt. J.B.M. Vranken), TvGR 2005/26 (m.nt. C.J.J.M. Stolker $\&$ M.P. Sombroek-van Doorm).

53. Byleveld \& Brownsword 20oI, p. 288 (noot 48). 
vidu zich in voorkomende gevallen vrijheidsbeperkende maatregelen laten welgevallen om aantasting van zijn waardigheid te voorkomen. Deze inbreuk kan niet teniet worden gedaan met een beroep op de zelfbeschikking wegens strijdigheid met een - in de concrete situatie - hogere waarde, zoals de beschermwaardigheid van het leven..$^{54}$

Beide visies op de menselijke waardigheid zien wij terug in discussies over de rol van de overheid met betrekking tot de gezondheidszorg. Het mag niet verbazen dat de empowerment-aanhangers de nadruk leggen op het versterken van de keuzevrijheid en de zelfbeschikking van het individu. De patiënt moet zijn eigen zorgregisseur zijn en anderen moeten zich zo min mogelijk inlaten met zijn keuzes. De constraintaanhangers maken zich daarentegen zorgen over de implicaties van het toenemende aanbod van diagnostische, preventieve en therapeutische behandelingsopties. Zij haken daarbij aan bij een meer objectief geformuleerd waardigheidsconcept en pleiten voor meer aandacht voor de bescherming die waardigheid impliceert.

De bescherming en erkenning van iemands menselijke waardigheid vinden opnieuw plaats in een relationele betrokkenheid. Het vraagt om kennis van de persoon van de zorgvrager, meer in het bijzonder van zijn wensen en behoeften. Vanuit die betrokkenheid met 'de ander' kan een hulpverlener, als raadgever en meedenker, optimaal recht doen aan de zelfbeschikking. Aan deze autonomie van de patiënt zitten twee kanten (negatief en positief): de keuzes van de patiënt dienen van hemzelf te zijn (empowerment), waarbij een relationele context gewenst is om die keuzes daadwerkelijk van hemzelf te laten zijn (positieve en negatieve vrijheid), en de aard van de keuzes gaat niet in tegen de eigen menselijke waardigheid (constraint). Anders gezegd, het erkennen van iemands menselijke waardigheid vooronderstelt een concept van goede zorg ter verzekering of verwezenlijking van persoonlijke autonomie.

Voor een goed begrip van 'het recht op persoonlijke autonomie', zoals erkend door het EHRM, is het van belang te weten dat mensenrechten tot doel hebben de menselijke waardigheid te verzekeren. Vanwege deze nauwe verbondenheid met de menselijke waardigheid komt aan deze categorie rechten speciale betekenis toe in onze rechtsorde, alsmede in het gezondheidsrecht.

De speciale status van de rechten van de mens blijkt onder meer uit de omstandigheid dat zij, anders dan 'gewone rechten', niet nadrukkelijk door de staat hoeven te worden erkend om gelding te hebben. Mensenrechten zijn immers eigen aan het menszijn en als zodanig onvervreemdbaar: de staat kan personen hun mensenrechten en menselijke waardigheid niet ontnemen (vgl. de empowerment-visie op menselijke waardigheid). De noodzaak de menselijke waardigheid te allen tijde te verzekeren verplicht de overheid tegelijkertijd tot het nemen van maatregelen zodra deze waardigheid in gedrang komt. ${ }^{55}$ Mensenrechten bieden mensen derhalve de aanspraak om

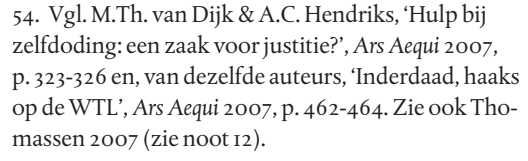


zich in alle vrijheid te ontplooien, maar daar staat tegenover dat mensen geen afstand kunnen doen van hun mensenrechten, althans voor zover zij daarmee geweld zouden doen aan hun waardigheid (vgl. waardigheid als constraint). Dit verklaart bijvoorbeeld het verbod van financieel voordeel met betrekking tot (bestanddelen van) het menselijk lichaam. ${ }^{56}$ Dit en soortgelijke verboden kunnen niet worden opgeheven met een beroep op de zelfbeschikking. De menselijke waardigheid is immers onaantastbaar. Menselijke waardigheid vraagt daarom zowel om eerbiediging (vrijheid van) als om bescherming (vrijheid tot)..$^{57}$

De betekenis die het EHRM toekent aan het recht op persoonlijke autonomie kan derhalve niet los worden gezien van de menselijke waardigheid, zoals dit erkenning en uitwerking heeft gevonden in zijn jurisprudentie. De menselijke waardigheid vormt voor het EHRM de belangrijkste waarde bij het inkleuren van de door het EVRM en de bijbehorende protocollen beschermde rechten en vrijheden. ${ }^{58}$ Dit begrip klinkt onder meer door in de uitleg van typische vrijheidsrechten, zoals de vrijheid van gedachte, geweten en godsdienst (art. 9), de vrijheid van meningsuiting (art. Io) en de vrijheid van vergadering en vereniging (art. II). Deze rechten waarborgen, aldus het EHRM, dat individuen vrijelijk kunnen bepalen hoe zij hun leven - al dan niet met anderen ${ }^{59}$ - willen inrichten. Dit duidt op de erkenning van autonomie in de zin van 'vrijheid van' ${ }^{60}$ en van menselijke waardigheid in termen van empowerment.

Een soortgelijke uitleg van het autonomie- en het achterliggende menselijke waardigheidsbegrip vinden we terug in de jurisprudentie van het Hof met betrekking tot het recht op privacy (art. 8). Hoewel het Hof van begin af aan heeft overwogen dat dit recht primair beoogt bescherming te bieden tegen willekeurige inmenging met het privé, gezins- en familieleven ${ }^{61}$ heeft het Hof eveneens erkend dat individuen aan dit recht aanspraken kunnen ontlenen om op effectieve wijze gebruik te kunnen maken van dit recht. ${ }^{62}$ In het verlengde hiervan rusten er positieve verplichtingen op de staat om de privacy en persoonlijke integriteit van individuen adequaat te beschermen. ${ }^{63}$ Het Hof heeft met betrekking tot het recht op privé-leven bij herhaling ook verwezen

56. Vgl. art. 2I Verdrag inzake de rechten van de mensen en de biogeneeskunde.

57. Vgl. art. I van het Handvest van de grondrechten van de Europese Unie: “De menselijke waardigheid is onschendbaar. $\mathrm{Zij}$ moet worden geëerbiedigd en beschermd". Handvest van de grondrechten van de Europese Unie, PbEG 200o, C 364/I-22.

58. EHRM 29 april 2002, Pretty t. het VK (zie noot 3), $\S 65$. Zie ook W. Thomassen, 'Samenleven met verschillen', in: R. Holtmaat (red.), Gelijkheid en (andere) grondrechten, Deventer: Kluwer 2004, p. I2I-I37 (p. I22I23).

59. EHRM I6 december 1992, Niemietz t. Duitsland, nr. I373I/88, NJ 1993, 400 (m.nt. E.J. Dommering), NJCMBulletin 1993, p. 320 (m.nt. B.E.P. Myjer), § 29: “Respect for private life must also comprise to a certain degree the right to establish and develop relations with other human beings".

6o. EHRM iI januari 2006, Sørensen \& Rasmussen t. Denemarken (GC), nr. 52562/99 \& 52620/99, NJ 2007, I59 (m.nt. E.A. Alkema), EHRC 2006, 4I (m.nt. F. Dors- semont), § 54: "In this connection the notion of personal autonomy is an important principle underlying the interpretation of the Convention guarantees. This notion must therefore be seen as an essential corollary of the individual's freedom of choice implicit in Article II and confirmation of the importance of the negative aspect of that provision".

6I. EHRM 23 juli 1968, Belgische Taal, A-5/6, §7.

62. EHRM I3 juni I979, Marckx t. België, nr. 6833/74, NJ 1980, 462 (m.nt. E.A. Alkema), §31. Zie ook EHRM 26 maart I985, X \& Y t. Nederland, nr. 8978/80, NJ I985, 525 (m.nt. E.A. Alkema), NJCM-Bulletin I985, p. 4IO (m.nt. J.G.C. Schokkenbroek), § 23; EHRM 22 februari 1994, Burghartz t. Zwitserland, nr. I6213/90, NJ 1996, I2 (m.nt. E.A. Alkema), § 24, EHRM 24 februari 1998, Botta t. Italië, nr. 2I439/93, NJ 1999, 69 I (m.nt. E.J. Dommering), NJCM-Bulletin I998, p. 597 (m.nt. R.A. Lawson \& A.C. Hendriks), § 33 en EHRM 4 december 2007, Dickson t. het VK (GC), nr. 44362/o4, §7oo. 63. EHRM 26 maart $1985, X \& Y$ t. Nederland (zie noot 62). 
naar 'persoonlijke autonomie' als onderliggend beginsel ${ }^{64}$ om uiteindelijk over te gaan tot de erkenning van het 'recht op persoonlijke autonomie'. ${ }^{65} \mathrm{Om}$ deze persoonlijke autonomie van mensen, in de zin van menselijke waardigheid als empowerment, tot zijn recht te laten komen moet de staat individuen met rust laten ${ }^{66}$ en persoonlijke keuzes respecteren. Deze aanspraak op non-interventie met de keuzevrijheid is evenwel niet onbeperkt. Het tweede lid van artikel 8 EVRM bevat enkele beperkingsmogelijkheden, die deels kunnen worden opgevat als menselijke waardigheid als constraint. Zo is een staat gerechtigd, aldus het Hof, om sadomasochistische praktijken te verbieden ook al zijn alle betrokkenen volwassen, stemmen zij vrijwillig in met deze praktijken en vinden de handelingen uitsluitend plaats in de privé-sfeer. ${ }^{67}$ De menselijke waardigheid beperkt hier dus (het respect voor) de keuzevrijheid, ook van wilsbekwame personen.

Met betrekking tot het recht op leven (art. 2), het folterverbod (art. 3) en het verbod van slavernij en dwangarbeid (art. 4) - drie absolute rechten - heeft het Hof gekozen voor een andere accentuering van de verschillende dimensies van persoonlijke autonomie en menselijke waardigheid, een interpretatie die aansluit bij de vrijheid tot en waardigheid als constraint. Volgens vaste jurisprudentie van het EHRM omvat het recht op leven niet alleen het verbod mensen van het leven te beroven, maar tevens de verplichting het menselijk leven te beschermen. ${ }^{68}$ Deze positieve verplichting noopt staten zich in te spannen om te voorkomen dat individuen zelfmoord plegen ${ }^{69}$ of dat hun leven in gevaar komt door een hongerstaking ${ }^{70}$ dan wel dat zij anderszins voortijdig komen te overlijden. ${ }^{71}$ In dezelfde lijn oordeelde het Hof in de beroemde zaak Pretty door te overwegen, dat individuen met een beroep op artikel 2 EVRM niet het recht toekomt zelf te bepalen wanneer zij hun leven (laten) beëindigen. ${ }^{72}$ De plicht van de staat om het leven te beschermen prevaleert boven de persoonlijke autonomie. ${ }^{73}$ De waarde van het menselijk leven vormt hier een constraint ter rechtvaardiging van een beperking van de keuzevrijheid. Of, anders gesteld, de menselijke waardigheid verplicht hier tot het bieden van goede zorg boven het onthouden van zorg.

64. EHRM 7 februari 2002, Mikulic t. Kroatië, EHRC 2002, 25 (m.nt. H.L. Janssen), § 53; EHRM 29 april 2002, Pretty t. het VK (zie noot 3), § 61; EHRM II juli 2002, Christine Goodwin t. het VK (zie noot 4), §9o en EHRM i7 februari 2005, K.A. E A.D. t. België, nr. 42758 | $98 \& 45558 / 99$, EHRC 2005, $38, \S 83$.

65. EHRM 20 maart 2007, Tysiąct. Polen, nr. 54Io/03, NJCM-Bulletin 2007, p. 497 (m.nt. A.C. Hendriks), § I07 en EHRM Io april 2007, Evans t. het VK (GC) (zie noot 2), $\S 7 \mathrm{I}$.

66. Vgl. rechter Walsh in EHRM 22 oktober I98I, Dudgeon t. het VK, nr. 7525/76, A-45 en rechter Zupančič in EHRM 24 juni 2004, Von Hannover t. Duitsland, NJ 2005, 22 (m.nt. E.J. Dommering), EHRC 2004, 79 (m.nt.J.H. Gerards), NJCM-Bulletin 2004, p. II7I (m.nt. V.J. de Graaf).

67. EHRM I9 februari I997, Laskey, Jaggard \& Brown t. het VK, nr. 21627/93; 21826/93 en 21974/93, § 44: "The determination of the level of harm that should be tolerated by the law in situations where the victim consents is in the first instance a matter for the State concerned since what is at stake is related, on the one hand, to public health considerations and to the general deterrent effect of the criminal law, and, on the other, to the personal autonomy of the individual". Zie ook EHRM I7 februari 2005, K.A. \& A.D. t. België (zie noot 64).

68. EHRM 9 juni I998, L.C.B.t. het VK, nr. 23413/94, NJ I999, 283, §36; EHRM 28 oktober I998, Osman t. het VK (GC), nr. 46477/99, NJ 2000, I334 (m.nt. E.A. Alkema), NJCM-Bulletin I999, p. 512 (m.nt. B.E.P. Myjer), § II5. Vgl. EHRM 3 I mei 2007, Kontrovát. Slovakije, nr. 75IO/ 04, EHRC 2007, 85 en EHRM 9 oktober 2007, Saoud t. Frankrijk, nr. 9375/o2, EHRC 2007, 135, GJ 2007 (m.nt. A.C. Hendriks), §99.

69. EHRM 3 april 200I, Keenan t. het VK, EHRC 200I, 37 (m.nt.J.H. Gerards), § 9I en EHRM 7 juni 2005, Ktlınç e.a. t. Turkije, nr. $40145 / 98$.

7o. ECieRM 20 oktober 1997, Ilijkov t. Bulgarije, nr. 33977/96 en EHRM 5 april 2005, Nevmerzhitskyt. Oekraïne, GJ 2005, 63 (m.nt. A.C. Hendriks), NJCMBulletin 2005, p. 992 (m.nt. P.C. Vegter). 7I. EHRM 23 mei 2006, Taïs t. Frankrijk (GC), nr. 39922 / 03.

72. EHRM 29 april 2002, Pretty t. het VK (zie noot 3), $\S 39$.

73. EHRM 29 april 2002, Pretty t. het VK (zie noot 3), $\S 6$ I. 
Uit de jurisprudentie van het EHRM met betrekking tot artikel 3 EVRM - inzake het verbod van foltering en van onmenselijke of vernederende behandeling of bestraffing - blijkt dat dit verbod zowel negatieve als positieve verplichtingen omvat die nauw aansluiten bij de menselijke waardigheid. Op grond van dit verbod is het een staat verboden personen te onderwerpen aan foltering en onmenselijke of vernederende behandeling of bestraffing (negatieve verplichting) en is zij gehouden te voorkomen dat personen aan dergelijke vormen van behandeling of bestraffing worden blootgesteld (positieve verplichting), ook indien de daders particulieren zijn. ${ }^{74}$ Artikel 3 EVRM omvat tevens "a positive obligation on the part of the State to protect the individual from acute ill-treatment, whether physical or mental, whatever its source". ${ }^{75}$ In dezelfde lijn bepaalde het EHRM met betrekking tot gedetineerden dat artikel 3 EVRM de positieve verplichting omvat voor de Staat "de s'assurer qu'un prisonnier est détenu dans des conditions compatibles avec le respect de la dignité humaine ..." ${ }^{76}$ De menselijke waardigheid is daarmee een hard criterium - en een absolute (onder)grens - waarmee iedere vorm van behandeling in overeenstemming moet zijn.

Met betrekking tot de zorg aan en ondersteuning van mensen is het mensenrechtelijke uitgangspunt dat individuen alleen na geïnformeerde toestemming mogen worden behandeld. ${ }^{77}$ Behandelen zonder toestemming is niet alleen strijdig met het informed consent-beginsel, en daarmee met artikel 8 EVRM, maar kan ook de menselijke waardigheid als zodanig aantasten. In het verlengde hiervan heeft het Hof bij herhaling uitgemaakt dat het onderwerpen van een persoon aan dwangbehandeling een vorm van onmenselijke of vernederende behandeling of bestraffing kan opleveren in de zin van artikel 3 EVRM. $^{78}$ Dit laatste veronderstelt in ieder geval dat sprake is van een minimumniveau van leedtoevoeging ${ }^{79}$ dat uitstijgt boven hetgeen eigen is aan de betreffende behandeling. ${ }^{80} \mathrm{Om}$ te beoordelen of mishandeling (ill-treatment) valt binnen de reikwijdte van artikel 3 EVRM kijkt het Hof ook naar het geslacht, de leeftijd en de gezondheidsstatus van de betrokkene. ${ }^{8 \mathrm{r}}$ Ook zonder de intentie te hebben mensen te vernederen of te verlagen kan sprake zijn van een vernederende behandeling. ${ }^{82}$ Dit doet zich voor, zo leert de rechtspraak van het Hof, bij routinematige visitatie van

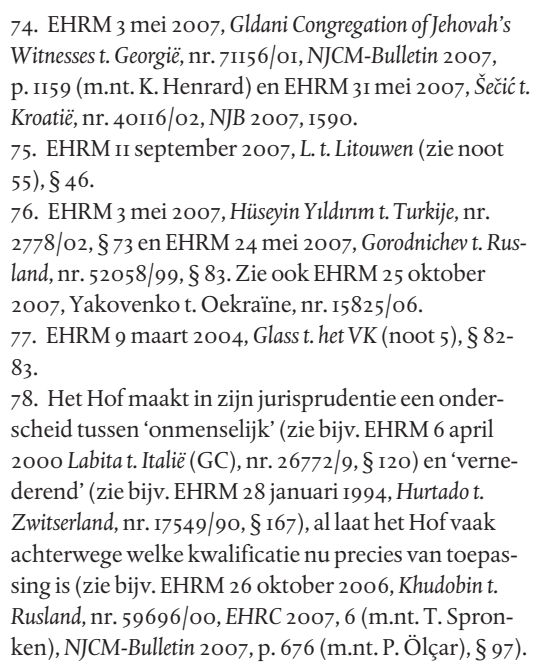

79. Zie bijv. EHRM I8 januari I978, Ierland t. het VK, nr. 53IO/7I, § I62; EHRM 25 april I978, Tyrer t. het VK, nr. 5856/72, § 29-30; EHRM I4 november 2002, Mouisel t. Frankrijk, nr. 67263/oI, EHRC 2003, 2 (m.nt. G. de Jonge), § 37 en EHRM Io februari 2004, Gennadi Naoumenko t. Oekraïne, nr. 42023/98, § 108.

8o. EHRM 6 april 2000 Labita t. Italië (GC), (noot 78 ), $\S$ I20; EHRM 28 oktober 1998, Assenov e.a. t. Bulgarije, nr. 2476o/94, § 94 en EHRM 9 juni I998, Tekin t. Turkije, nr. 22496/93, § 52-53.

8I. EHRM I8 januari 1978, Ierland t. het VK (zie noot 79); EHRM I6 december I999, V.t. het VK (GC), nr. 24888 94, EHRC 2000, I5 (m.nt. J.van der Velde), § 70 en EHRM I9 april 20oI, Peers t. Griekenland, nr. 24888/94, EHRC 200I, 42 (m.nt. G. de Jonge), § 67.

82. EHRM I6 december 1997 Raninen t. Finland, nr. 20972/92, § 55; EHRM I6 december I999, V. t. het VK (zie noot 8I), § I62; EHRM io juli 20oI, Price t. het VK, nr. 33394/96, NJCM-Bulletin 2002, p. 28 I (m.nt. M. Hagens \& A.C. Hendriks), EHRC 200I, 53 (m.nt. G. de Jonge), § 30 en EHRM I4 december 2006, Filip t. Roemenië,nr. 4II24/02, §37. 
gedetineerden. ${ }^{83}$ Indien dit minimumniveau niet is gehaald, kan nog altijd sprake zijn van een schending van artikel 8 EVRM. Dit laatste duidt dan op een gradueel minder ernstige schending van de menselijke waardigheid. ${ }^{84} \mathrm{Om}$ te bepalen of dwangbehandeling strijdig is met artikel 3 EVRM, kijkt het Hof onder meer of de behandeling wordt uitgevoerd door of onder verantwoordelijkheid van een arts, ${ }^{85}$ of er procedurele waarborgen zijn, ${ }^{86}$ naar de pijn of het lijden dat door de behandeling wordt veroorzaakt, ${ }^{87}$ de mate waarin er geweld is gepleegd bij de dwangbehandeling, ${ }^{88}$ en naar eventuele schadelijke gevolgen van de behandeling voor de gezondheid van de betrokkene. ${ }^{89}$

Het bovenstaande laat onverlet dat behandeling en mishandeling verschillende begrippen zijn. Zo kan het onthouden van een noodzakelijke behandeling (de vrijheid tot) net zozeer een schending opleveren van artikel 3 EVRM. ${ }^{90}$ "With respect to medical interventions to which a detained person is subjected against his or her will, Article 3 of the Convention imposes an obligation on the State to protect the physical wellbeing of persons deprived of their liberty, for example by providing them with the requisite medical assistance." ${ }^{\text {II }}$ Artikel 3 bevat dus geenszins een verbod om wilsbekwame personen aan een gedwongen behandeling te onderwerpen, maar garanties dat die behandeling aan bepaalde eisen voldoet en dat met het oog op legitieme doelen - in het bijzonder het bijdragen aan de ontplooiing - daartoe wordt overgegaan.

Uit de jurisprudentie van het Hof volgt niet dat (therapeutische) dwangbehandeling, ${ }^{92}$ waarbij de integriteit van het individu in het geding is, slechts mag worden overwogen om het leven van een persoon te beschermen. In navolging van de Europese Commissie voor de Rechten van de Mens (ECieRM) legt het Hof het beginsel van 'medische noodzakelijkheid' aanzienlijk ruimer uit dan 'levensreddend'. ${ }^{93}$ Of, zoals het Hof onlangs nog overwoog: “... a measure which is of therapeutic necessity from a point of view of established principles of medicine cannot be regarded as inhuman and degrading...The same can be said about force-feeding that is aimed at saving the life of a particular detainee who consciously refuses to take food". ${ }^{94} \mathrm{Het}$ Hof lijkt hiermee te erkennen dat het bieden van goede zorg een geoorloofde inperking kan zijn van autonomie als afweerrecht. Dit ter voorkoming van inbreuken op de menselijke

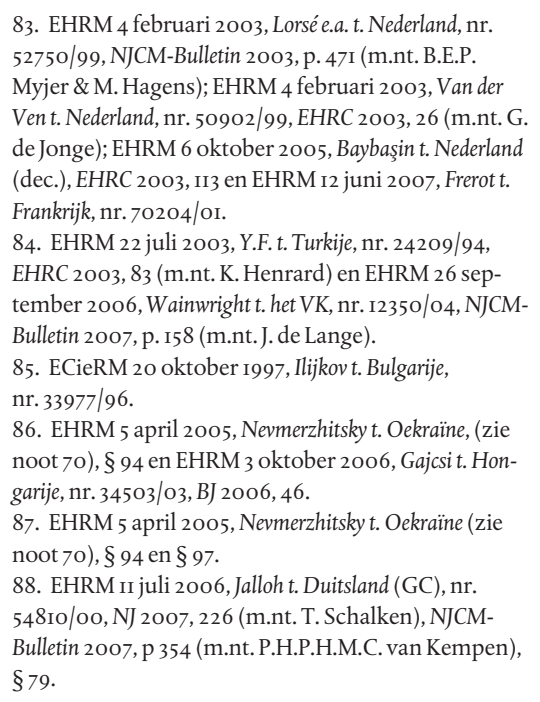

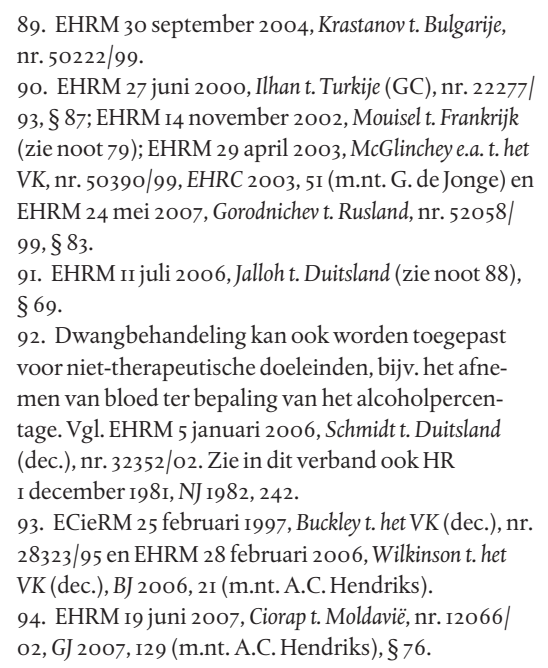


waardigheid. Het Hof heeft in aansluiting hierop herhaaldelijk geoordeeld dat een noodzakelijke (dwang)behandeling geen schending oplevert van artikel $3 \mathrm{EVRM}^{95} \mathrm{en}$ dat het bieden van zorg en ondersteuning ook de onvrijwillige opname in een verzorgingstehuis kan rechtvaardigen (art. 5 lid I EVRM). ${ }^{96}$

Hieruit volgt dat het Hof bij de uitleg van EVRM-rechten de (gevolgen van een behandeling of nalaten voor de) menselijke waardigheid voorop stelt. Dit verklaart waarom het Hof aan het 'recht op persoonlijke autonomie' een substantieve notie toevoegt, ${ }^{97}$ in de zin van dat de uitleg van het autonomiebegrip verenigbaar moet zijn met het beginsel van goede zorg en de menselijke waardigheid.

Bestudering van de rechtspraak van het EHRM leert dat individuen de vrijheid toekomt om zonder bemoeienis van anderen richting te geven aan het eigen leven, maar dat - ook zonder dat de rechten en vrijheden van anderen in het geding zijn ${ }^{98}$ - die vrijheid kan worden beperkt indien de zelfbeschikking een bedreiging vormt voor fundamentele waarden. ${ }^{99}$ Artikel 3 en artikel 8 EVRM vervullen in dit verband een belangrijke schakelfunctie: aan deze rechten kunnen zowel negatieve als positieve vrijheden worden ontleend ter verwezenlijking van een menswaardig bestaan. De conclusie luidt, dat het Hof het toelaatbaar acht grenzen te stellen aan de uitoefening van de 'vrijheid van' indien de wijze waarop van de zelfbeschikking gebruik wordt gemaakt onverenigbaar is met de menselijke waardigheid of andere in een democratische samenleving fundamentele waarden. ${ }^{\text {IOo }}$

Dit alles wijst op een bepaalde inkleuring door het Hof van het begrip persoonlijke autonomie, in de zin dat het Hof inhoudelijke, substantieve criteria voor ogen heeft waaraan de invulling van de zelfbeschikking wordt beoordeeld. ${ }^{\text {Ior }} \mathrm{Het} \mathrm{Hof} \mathrm{gaat} \mathrm{hierbij}$ uit van de waardigheid van iedere persoon en de verenigbaarheid van de individuele zelfbeschikking met andere fundamentele waarden. Kortweg komt dit erop neer dat een beroep op door het EVRM en de bijbehorende protocollen beschermde rechten en (bovenal negatieve) vrijheden faalt, indien het handelen van het individu zijn waardigheid geweld aandoet of anderszins in een democratische samenleving niet hoeft te worden getolereerd. Zo'n beperking van de zelfbeschikking wordt, zoals hierboven aangegeven, ook toelaatbaar geacht indien nodig geacht ter vergroting van de moge-

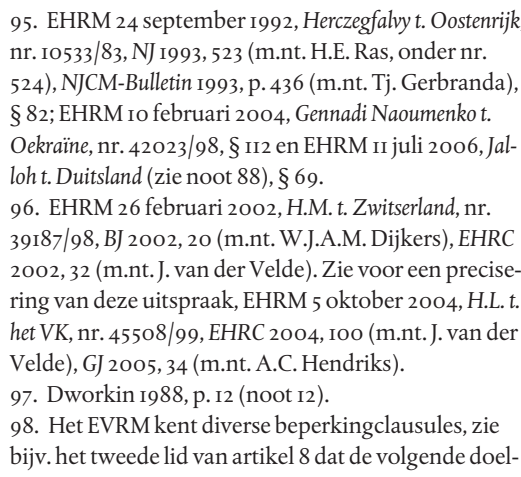

criteria noemt: "in het belang van de openbare veilig heid, voor de bescherming van de openbare orde, gezondheid of goede zeden of voor de bescherming van de rechten en vrijheden van anderen". 99. EHRM 29 juni 2004, Leyla Sahin t. Turkije, nr. 44774 98, AB 2004, 338 (m.nt. B.P. Vermeulen), NJCM-Bulletin 2005, p. 172 (m.nt. E.M.H. Hirsch Ballin), § Io6. Ioo. Vgl. EHRM in september 2006, Konrad e.a.t. Duitsland (dec.), nr. 35504/03, EHRC 2007, I4 (m.nt. H.-M.Th.D. ten Napel).

IOI. M. Hooghe, 'Procedurale en substantieve vrijheidsconcepten binnen het politiekliberalisme', in: S. Gatz \& P. Stouthuysen (red.), Een vierde weg? Linksliberalisme als traditie en als oriëntatiepunt, Brussel: VUB University Press 200I, p. 79-IOI. 
lijkheden en ontplooiingskansen van het individu ('vrijheid tot'). Dit alles heeft in het bijzonder repercussies voor minderjarigen alsmede voor mensen met een psychiatrische stoornis, een verstandelijke beperking of dementie.

6.I 'Principled' en relationele autonomie

Deze benadering van het Hof lijkt te wijzen op een vorm van principled autonomy. O'Neill introduceerde deze term in 20oI in reactie op de binnen bepaalde sectoren van de ethiek - en het (gezondheids)recht - dominante autonomievisie. ${ }^{\text {IO2 }}$ Volgens deze opvatting komt binnen zorgrelaties aan autonomie meer waarde toe dan de andere medisch-ethische beginselen (goed doen, niet schaden en rechtvaardigheid). Voortbouwend op het Kantiaanse gedachtegoed heeft O'Neill getracht deze beginselen meer met elkaar te verbinden en in balans te brengen. Zij heeft daarbij het belang van vertrouwen en van verantwoordelijkheid benadrukt en de importantie van de juridisering van zorgrelaties en de grote aandacht voor keuzevrijheid gerelativeerd. In plaats van een 'consumentistische' opvatting van persoonlijke autonomie pleit O'Neill voor de idee dat een autonoom persoon verantwoordelijkheid aanvaardt voor zijn keuzes. Iemand brengt zijn autonomie tot uitdrukking door beslissingen te nemen die in overeenstemming zijn met datgene wat hem bindt en verplicht in het leven. ${ }^{103}$ Een soortgelijke substansieve opvatting van autonomie zien we terug bij auteurs die pleiten voor een relationele autonomie (relational autonomy). ${ }^{\text {I04 }}$

Relationele autonomie gaat uit van de veronderstelling dat het vermogen van individuen om hun autonomie te ontwikkelen moet worden gezien in de context van sociale relaties met anderen, die dit vermogen cultiveren; de inhoud van autonomie moet worden begrepen in relatie tot gedeelde normen en waarden. ${ }^{\text {105 }}$ Autonomie, aldus bezien, is niet alleen afhankelijk van de vermogens van een individu, maar moet ook worden gezien in het licht van relaties met anderen en de binnen die context evoluerende opvattingen. Een hulpverlener kan door het bieden van goede zorg bijdragen aan het versterken of herstellen van de persoonlijke autonomie.

\subsection{Lessen voor het (gezondheids)recht}

De rechtspraak van het EHRM en het discours rond de begrippen principled en relationele autonomie lijken te pleiten voor een zekere nuancering van persoonlijke autonomie als vrijwel absolutistisch afweerrecht van de patiënt en voor de erkenning van het beginsel van goede zorg als uitgangspunt in zorgrelaties. Hoewel nauwelijks uitgewerkt spreekt dit ook uit de Beleidsbrief ethiek, waarin de gelijkwaardigheid van autonomie, de beschermwaardigheid van het leven en goede zorg wordt onderstreept. ${ }^{\text {106 }}$ Kenmerken van goede zorg zijn dan dat de zorg aansluit bij de wensen en behoeften van de patiënt en gericht is op het vergroten van zijn mogelijkheden en ontplooiings-

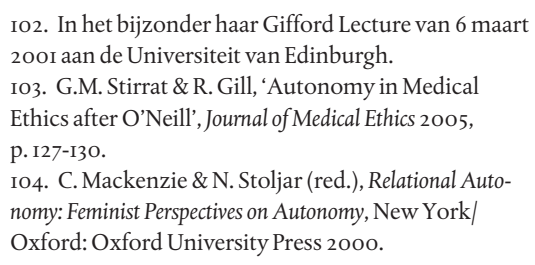

I05. R. Gilbar, The Status of the Family in Law and Bioethics, Aldershot: Ashgate 2005, p. 50 e.v. Zie ook J. Herring \& P.-L. Chau, 'My Body, Your Body, Our Bodies', Medical Law Review 2007, p. 34-6I (p. 45-49) en J. Nedelsky, 'Recognising Autonomy: Sources, Thoughts, and Possibilities', Yale Journal of Law and Feminism 1989, p. 7-36. Io6. Beleidsbrief ethiek, p.3 (zie noot 9). 
kansen - ergo: zijn autonomie. Dit legt zowel verantwoordelijkheden op de staat ${ }^{\mathrm{IO}}$ als op de hulpverlener, waaronder de plicht om te sturen en, zo nodig, te interveniëren. Eerder omschreven wij goede zorg in dit verband als zorg die op aandachtige, verantwoordelijke, competente en responsieve wijze wordt gegeven en ontvangen. Verkerk benadrukt daarbij dat de zorgrelatie tussen hulpverlener en patiënt dialogisch van aard is. ${ }^{\text {Io8, }}$ Io9

Wat betekent dit alles voor het (gezondheids)recht, meer in het bijzonder voor de rechtspositie van patiënten en cliënten die met zorgaanbieders krijgen te maken? Het 'recht op persoonlijke autonomie' uitleggen op de wijze die aansluit bij de rechtspraak van het EHRM en die wordt bepleit door de aanhangers van een meer principled en relationele visie op autonomie, betekent dat (gezondheidsrecht)juristen autonomie meer dan thans het geval is in samenhang met andere waarden en beginselen dienen te bezien. De (negatieve) 'vrijheid van' wordt dan aangevuld met de (positieve) 'vrijheid tot', met aandacht voor mogelijkheden en ontplooiingskansen van de betrokkene. Een mens heeft immers weinig aan keuzevrijheid als hij niet weet goed te kiezen. Voorts impliceert dit dat er meer aandacht komt voor de persoonlijke situatie van de patiënt (o.a. leeftijd, verstandelijke vermogens, familie en sociale relaties) en de context waarin deze zich bevindt (o.a. mate van afhankelijkheid, effect van hulpvraag op welbevinden, etc.) en de invloed van dit alles op zijn mondigheid en de uitoefening van zijn keuzevrijheid. ${ }^{\text {IIO }}$ Het 'overschatten' van het vermogen om zelf te kunnen kiezen en beslissen kan immers tot gevolg hebben dat mensen noodzakelijke zorg mislopen en anderszins onvoldoende worden beschermd. Dit laat onverlet dat aandacht voor autonomie en zelfbeschikking, in de zin van 'vrijheid van', geboden blijft. Verkerk is van mening dat respect voor autonomie een belangrijk wapen is tegen de macht en overheersing waarmee patiënten en cliënten in de zorg te maken krijgen: "te lang en te vaak zijn cliënten geconfronteerd geweest met - goedbedoelde - paternalistische handelingen van hulpverleners. Het inzetten van het respect voor individuele autonomie als belangrijke waarde werkt daarom als een soort van wapen tegen zorg als macht en overheersing. Een belangrijk wapen (..) in die zorgpraktijken waar mensen al kwetsbaar en afhankelijk zijn en zich ook als zodanig gedragen". ${ }^{\text {II }}$

De betekenis van het 'recht op persoonlijke autonomie', zoals dat onlangs op Europees niveau erkenning heeft gevonden, is in deze bijdrage nader onder de loep genomen. Daartoe is gekeken zowel naar de ethische en rechtstheoretische literatuur, als positiefrechtelijke bronnen, meer in het bijzonder de rechtspraak van het EHRM. Met betrekking tot de gezondheidszorg en het gezondheidsrecht leidt deze analyse tot de conclusie dat persoonlijke autonomie in samenhang met goede zorg moet worden

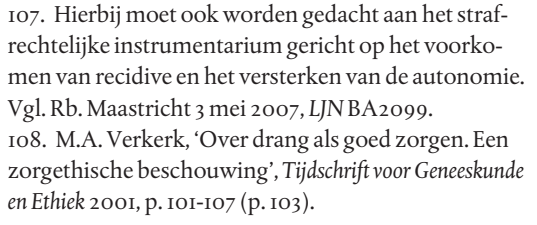
rechtelijke instrumentarium gericht op het voorkomen van recidive en het versterken van de autonomie. Vgl. Rb. Maastricht 3 mei 2007, LJN BA2099. Io8. M.A. Verkerk, 'Over drang als goed zorgen. Een zorgethische beschouwing', Tijdschrift voor Geneeskunde en Ethiek 2OOI, p. IOI-IO7 (p. IO3).

I09. Deze definitie van goede zorg is afgeleid van J. Tronto, Moral boundaries: a political argument for an ethic of care, New York/Londen: Routledge 1993. IIo. D.P. Engberts, Met recht en reden. Het gemeenschappelijke belang van medische ethiek en gezondheidsrecht (oratie Leiden), Houten: Bohn Stafleu van Loghum 2006, p. 7. III. Verkerk 200I, p. IOI-IO2 (zie noot Io8) en Frederiks 2004, p. 87-88 (zie noot 36). 
bezien. Wanneer, zoals het EHRM gebruikelijk is te doen, de menselijke waardigheid als uitgangspunt wordt genomen, liggen zelfbeschikking en goede zorg in elkaars verlengde in plaats van dat zij tegengestelde waarden belichamen. Zelfbeschikking zonder aandacht voor goede zorg dreigt een normatief inhoudsloos begrip te worden, terwijl zorg zonder aandacht voor de wensen en behoeften van de betrokkene zijn doel voorbijschiet. Zorg moet mensen optimaal in staat stellen hun leven als van henzelf te ervaren, hetgeen niet alleen vraagt om aandacht voor de eigen wil maar ook voor de interdependentie en relationele aspecten.

In navolging van het EHRM en pleidooien van aanhangers met een meer principled en relationele visie op autonomie is hierboven daarom betoogd dat het 'recht op persoonlijke autonomie' niet strikt individualistisch en als een vrijwel absoluut afweerrecht moet worden uitgelegd ('vrijheid van'), maar in samenhang met andere belangrijke juridische en ethische waarden, waaronder de 'vrijheid tot'. Zo is het bij de zorgverlening van belang aandacht te besteden aan de persoonlijke situatie van de patiënt en de context waarin deze zich bevindt. Dit kan thans, via de huidige wetgeving, het best worden bewerkstelligd via een substantieve inkleuring van de eisen van informed consent (art. 7:448-450 BW), het goed hulpverlenerschap (art. 7:453 BW) en van verantwoorde zorg (art. 40 Wet BIG en art. 2 KWZ).

Bovenstaande visie op persoonlijke autonomie dient te worden geïntegreerd in de bestaande en op stapel staande gezondheidswetgeving en -beleid, waaronder de patiëntenwetgeving. Zij dient ook anderszins te worden uitgedragen in de zorg en door het gezondheidsrecht. Dit heeft onder meer gevolgen voor de (bepleite) wijzigingen van de Wet Bopz, ${ }^{\text {II2 }}$ voor zowel de psychiatrie als de verstandelijk gehandicaptenzorg en psychogeriatrie, en het voornemen te komen tot een Wet cliënt (of consument). ${ }^{113}$ Hierbinnen dient meer aandacht te komen voor - en gewicht te worden toegekend aan - het bieden van goede zorg, vertrouwen en verantwoordelijkheid, naast de erkenning van de uniciteit en eigen identiteit van iedere mens.

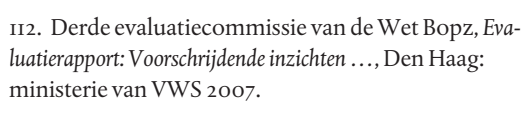

